\title{
Anti-Trafficking Interventions in Nigeria and the Principal- Agent Aid Model
}

\author{
Victoria I Nwogu
}

\begin{abstract}
Following the rising profile of trafficking in persons globally and Nigeria's position as a critical country in the African region, significant-though insufficient and poorly spent-funding has been deployed towards tackling the problem. This funding, however, is provided in a 'principal-agent' relationship by donors to the government of Nigeria and anti-trafficking organisations. Donors (the principals) fund organisations (the agents) to do work they deem important, though organisations tend to have significantly different needs and preferences for the funding. The consequence is that interventions paid for by these funds are 'not fit for purpose', making their outcomes often invisible, undesirable or unsustainable. An ancillary and critical issue related to anti-trafficking funding in Nigeria is accountability, or rather a lack of accountability. Where key actors in addressing trafficking are not accountable to beneficiaries, they miss out on critical feedback to help them improve services or design appropriate interventions.
\end{abstract}

Key words: Nigeria, NAPTIP, WOTCLEF, WOCON, IOM, UNODC, UNICEF, principal-agent, accountability, anti-trafficking, funding

Please cite this article as: V I Nwogu, 'Anti-Trafficking Interventions in Nigeria and the Principal-Agent Aid Model', Anti-Trafficking Review, issue 3, 2014, pp. 41-63, www.antitraffickingreview.org

\footnotetext{
1 With the kind research assistance of Ize Adava, Head of Public Relations and Resource Mobilization at the Lift up Care Foundation (LUCAF) in Nigeria. Her research interests include: HIV prevention, trafficking and migration (relating to health and wellbeing), human rights and gender. Email: twizad4ever@yahoo.com

This is an open-access article distributed under the terms of the Creative Commons Attribution License (CC-BY). Under the CC-BY license, the public is free to share, adapt, and make commercial use of the work. Users must always give proper attribution to the author(s) and the Anti-Trafficking Review.
} 


\section{Introduction}

Nigeria is a significant country in terms of anti-trafficking work, with a larger number of emigrants and trafficked persons compared with other countries on the African continent. ${ }^{2}$ To match this, a significant amount of funds has been channelled to Nigeria since 2001 to finance anti-trafficking interventions. In terms of these interventions, Nigeria has recorded many firsts, such as being the first in Africa to enact anti-trafficking legislation in 2003 and the first to establish a specialised, multi-functional anti-trafficking agency, the National Agency for Prohibition of Traffic in Persons and Other Related Matters (NAPTIP), which today is the focal agency for all anti-trafficking efforts in Nigeria. Nigeria was also the first country in Africa to record successful anti-trafficking prosecutions, with 220 convictions to date. ${ }^{3}$ It leads the Economic Community of West African States (ECOWAS $)^{4}$ in finding lasting sub-regional solutions to international trafficking and migration. At the national level, a National Policy on Protection and Assistance to Trafficked Persons (subsequently 'Protection Policy') was adopted in 2008 with the aim of providing 'appropriate and relevant services that will empower [victims of trafficking] for effective integration into their various communities'. ${ }^{5}$

This article discusses funding for anti-trafficking efforts in Nigeria to date and its impact. Ultimately, we will show that certain areas are 'favoured' for funding above others, e.g. prevention, prosecution and voluntary return of migrants, as opposed to promoting safe migration $^{6}$ or effective victim re-integration, though the latter is the purported aim of the Protection Policy. The article also speaks to how the anti-trafficking 'players' have been obliged through aid dependency to focus on certain aspects of intervention and ignore others. Funding is provided in a 'principal-agent' relationship by donors to the government of Nigeria and other anti-trafficking organisations.

No studies have been made specifically of funding (impact, sufficiency, nature and accountability) and anti-trafficking work in Nigeria, although references to sufficiency of funding for anti-trafficking efforts feature in most of the available donor reports by for instance different United Nations (UN) agencies and successive United States (US) Department of State Trafficking in Persons Reports (TIP Reports). Human trafficking as a phenomenon cannot be studied or addressed outside the broader human development framework, as the problem has cause-and-effect links to other issues that underpin development such as: good governance and rule of law, poverty, gender and other social inequalities, health, corruption, globalisation, migration and economic growth. ${ }^{7}$ This article places anti-trafficking funding within a larger discourse of development funding and makes the argument that

\footnotetext{
${ }^{2}$ United Nations Office on Drugs and Crime (UNODC), Global Trafficking Patterns, 2006, p. 22.

${ }^{3} \mathrm{~N}$ M Akede, 'No Safe Haven for Human Traffickers in 2014-(NAPTIP BOSS)', press release, NAPTIP, 9 Jan 2014, retrieved 1 April 2014, http://www.naptip.gov.ng/nosafehaven.html

${ }^{4}$ The Economic Community of West African States created in May 1975 to promote economic trade, national cooperation and monetary union, for growth and development throughout West Africa.

${ }^{5}$ NAPTIP, National Policy on Protection and Assistance to Trafficked Persons in Nigeria, 2008, p.4. In 2009, ECOWAS Ministers, drawing inspiration from Nigeria, adopted a similar policy with identical objectives and content.

${ }^{6}$ If this study were to expand in scope to closely examine prevention funding, it is likely that findings would reveal that in the Nigerian context significant funding has been geared towards preventing or discouraging migration, rather than to safe migration programming, which recognises that migration is a choice and a valid option for many people.

${ }^{7}$ Human trafficking does not occur in a vacuum. It is driven by socio-economic factors and, in turn, impacts on society in diverse ways. Inevitably, any discourse on human trafficking will certainly touch on development issues to some degree. In a note, Human Trafficking: A brief overview, 2009, the World Bank found that the problem of human trafficking cuts across a range of development issues, from poverty to social inclusion, to justice and rule of law issues, and thus has relevance for practitioners throughout the development community. The note therefore offered 'some potential orientations for the World Bank Group to further engage this issue in its operations'. See:

http: / / siteresources.worldbank.org/EXTSOCIALDEVELOPMENT/Resources/244362-1239390842422/6012763-

1239905793229/Human_Trafficking.pdf (retrieved 7 August 2014).
} 
anti-trafficking funding in Nigeria has suffered from many of the pitfalls of other development programmes.

In his seminal work, The White Man's Burden, William Easterly finds that: 'Rich-country politicians control the foreign aid agencies. To make the relationship between rich-country politicians and aid bureaucracies more precise, think of principals and agents (an agent is anyone who acts on behalf of another person, the principal...). Think of the rich-country politician as the principal and the aid bureaucrat as the agent. The big problem... is that the principal is the rich-country politician and not the real customers, the poor in poor countries. $^{, 8}$ The principal-agent relationship described by Easterly is problematic for sustainable development because investments are not driven by knowledge or experience of realities on the ground and the real needs of the people. In making his argument, Easterly separates donors and other development actors into two categories, the 'planners' and the 'searchers'. The planners propose solutions in a top-down approach through grand 'plans' by people (bureaucrats, foreign aid agencies or transnational companies) often completely removed from local contexts underpinning the problems for which they offer solutions. Searchers on the other hand find solutions for specific needs through a bottom-up approach and often work without donor funding. For Easterly, accountability is equally problematic because it is often accountability to a bigger political agenda in the donor country, rather than the people for whom aid is intended. He expresses shock at how little growth (or improvement) exists to show for 'massive' amounts of aid flows to developing countries. Citing various examples throughout the book, Easterly illustrates how community-driven initiatives or local innovations by 'searchers' can prove to be more successful and sustainable. Others, such as Sachs, propose a sweeping increase in aid allocations. ' Easterly's recommendations for the future of aid caution against the high propensity for corruption and aid diversion if channelled through bureaucracies. Rather, he proposes decentralisation, backing piecemeal local innovation, abandonment of the one-size-fits-all grand plans, and increased focus on accountability.

In the Nigerian anti-trafficking sector, donors (the principals) fund anti-trafficking organisations (the agents) to do work they have determined is important, though the organisations discussed in this article have different needs and preferences for how the funding is used. The article further discusses how, without accountability to beneficiary communities or constituencies, anti-trafficking funding does not meet specific needs, and efforts often become unsuccessful and unsustainable.

It is not within the capacity of this study to examine all anti-trafficking efforts in Nigeria. The author approached the main anti-trafficking players (government, non-governmental, intergovernment organisations and donors covering the different aspects of trafficking and ensuring geographical scope) in Nigeria via email and visits to conduct interviews. However, direct information received through survey questionnaires sent out between November 2013 and March 2014 was minimal. Of the six main anti-trafficking non-governmental organisations

\footnotetext{
${ }^{8}$ W Easterly, The White Man's Burden: Why the West's efforts to help the rest have done so much ill and so little good, Oxford University Press, 2007, p. 148.

9 J Sachs, The End of Poverty: Economic possibilities for our time, Penguin Books, New York, 2005. Collier, however, strikes a balance between the views of Easterly and Sachs and proposes that disbursing large volumes of aid alone is not the answer. For Collier, there needs to be more involvement of the foreign donors in a combination of approaches requiring: more risk-taking by aid agencies, military interventions in conflict-ridden countries to protect democracies, the setting of standards and regulations to encourage good governance reforms and free trade policies that also grant preferential access to exports for the bottom billion countries. P Collier, The Bottom Billion: Why the poorest countries are failing and what can be done about it, Oxford University Press, 2007.
} 
$(\text { NGOs })^{10}$ contacted, only two ${ }^{11}$ responded with detailed information. NAPTIP provided very broad information that is already in the public domain. No donor organisation responded, and of four UN agencies approached only one provided detailed information, whilst one other referred us to their general website where there was no specific information on their funding in Nigeria. This article therefore relied on additional sources such as donor reports, news reports and academic studies.

\section{Principals and Agents: Stemming the flow or creating diversions?}

The rise in awareness about human trafficking in Nigeria started in the late 1990s. Titi Atiku Abubakar, wife of the former vice-president of Nigeria, recalls the trip she undertook to study in Rome, Italy, from 1986-1987. Her observation of Nigerian women engaged in sex work on the streets of Rome changed the direction and focus of her working life. In 1999, she stood on her husband's ascendency to the office of vice-president to establish the Women Trafficking and Child Labour Eradication Foundation (WOTCLEF). ${ }^{12}$ Meanwhile, Bisi Olateru-Olagbegi, Executive Director of the Women's Consortium of Nigeria (WOCON), contributed to the first research study on the trafficking of women in Nigeria ${ }^{13}$ and launched the first national campaign against trafficking of women in $1997 .{ }^{14}$ Having confronted a problem of complex proportions, the pioneers of anti-trafficking interventions in Nigeria decided to act. Their efforts would require funds to meet specific objectives in an ecosystem of interventions that would need more (or different) aid than the aid givers were willing to grant.

Since the late 1990s, the main funders of anti-trafficking interventions in Nigeria have been the US Office to Monitor and Combat Trafficking in Persons, the European Union (EU), UN Global Initiative to Fight Human Trafficking (UN.GIFT), and the governments of Canada, France, Italy, Netherlands, Norway, Spain, Sweden, Switzerland and the United Kingdom (UK). Trafficking has remained a problem for Nigeria. The European Commission's Eurostat Trafficking in Humans Beings report highlights Nigeria among the top two countries of origin for victims of trafficking brought to EU countries from outside the EU. ${ }^{15}$ Similarly, the UK Border Agency's National Referral Mechanism (NRM) statistics have, since its inception in 2009, consistently placed Nigeria amongst the top three countries with the highest numbers of trafficked persons in the UK (i.e. those referred to the NRM). ${ }^{16}$

On a global level, the adoption of the UN Protocol to Prevent, Suppress and Punish Trafficking in Persons, Especially Women and Children in 2000 provided impetus for world governments and civil society to take more concerted action to address trafficking. Following hard on the heels of the Protocol was the first TIP Report published annually by the US State Department's Office to Monitor and Combat Trafficking in Persons. The report serves as a watchdog over the performance of the rest of the world in addressing trafficking. Resources

\footnotetext{
${ }^{10}$ These are GPI, WOTCLEF, COSUDOW, WOCON, Idia Renaissance, and IRRRAG identified by the UNODC as established, wellknown, reliable and serious, tend to work well with each other and coordinate their activities with government ministries and agencies. See: UNODC, Measures to Combat Trafficking in Human Beings in Benin, Nigeria and Togo, 2006, p. 100, retrieved 8 August 2014, http://www.unodc.org/pdf/human_trafficking/ht_research_report_nigeria.pdf

${ }^{11}$ WOCON and Idia Renaissance.

12 'Atiku \& I, Our Love Story - Titi Abubakar', The Street Journal Magazine, 2008, retrieved 26 February 2014, http://nigeriabusinesscommunities.com/profiles/blogs/2179753:BlogPost:2814

${ }^{13}$ As part of an African Regional Study on trafficking commissioned by the UN Special Rapporteur on violence against women, its causes and consequences, Radhika Coomaraswamy.

${ }^{14}$ See WOCON's website http://www.womenconsortiumofnigeria.org (retrieved 8 August 2014).

${ }^{15}$ European Union, Trafficking in Human Beings, Eurostat, 2013, p.10.

${ }^{16}$ United Kingdom Human Trafficking Centre, National Crime Agency (UK), National Referral Mechanism Statistics 2013, 2014, pp.3-4, retrieved 26 February 2014, http://www.nationalcrimeagency.gov.uk/publications/139-national-referral-mechanismstatistics-2013/file
} 
have followed documentary commitment from governments. In 2010, the US State Department's total global funding on the subject was USD 109.5 million, with $22 \%$ spent locally and $78 \%$ on global programmes in over 80 countries. Of the global package, $19 \%$ was spent in Africa. ${ }^{17}$ The EU, under its Migration and Asylum Thematic Programmes initiative, dedicated EUR 348 million (USD 466.32 million), ${ }^{18}$ from 2007 to 2013, to-among other migration-related objectives-protecting migrants against exploitation and exclusion and supporting the fight against trafficking in human beings. ${ }^{19}$ Other countries have also contributed significant amounts through bilateral agreements or multilateral donations via UN agencies or funds. The catch related to this global funding is that the measures it supports are often 'not fit for purpose', a phrase used by the Anti-Trafficking Monitoring Group (a UK group) to describe anti-trafficking measures in the UK under the Council of Europe Convention on Action against Trafficking in Human Beings. ${ }^{20}$ This study echoes the UK monitoring efforts in asking if the anti-trafficking funding in Nigeria is 'fit for purpose'. This research shows that not only are decisions about funding often top-down, but anti-trafficking-related funding in general appears to be focused on diversionary efforts: promoting the politics of foreign donors, skirting around the real issues and avoiding tangible solutions.

As has been observed in other development and aid fields, a significant reason why funding does not always meet the needs of its intended beneficiaries lies in the design of the larger funding system. Funding decisions are most often made at the pinnacle of bureaucracies (in donor countries), and then handed down to foreign aid agencies (most often in developing countries), in the form of a principal-agent relationship. Easterly found that: 'Voters in the rich country and their representatives are the ones who choose the actions of the foreign aid agency. They love the Big Plans, the promises of easy solutions, the utopian dreams, the side benefits for rich-country political or economic interests, all of which hands the aid agency impossible tasks. 21 There is very little consultation with people and practitioners on the ground-least of all with trafficked persons-to assess the most critical needs or the most effective initiatives to fund. ${ }^{22}$ The EU Migration and Asylum Thematic Programmes initiative, for instance, usually issues a call for proposals to identify potential initiatives to fund in yearly cycles. NGOs, UN and government institutions that apply have no say in these objectives and tend to adjust or abandon whatever strategic objectives they may have set for themselves in order to pursue the available funds.

\footnotetext{
${ }^{17}$ Office to Monitor and Combat Trafficking in Persons Washington, DC, U.S. Government Anti-Trafficking in Persons Program Funding, June 2011, retrieved 26 February 2014, http://www.state.gov/documents/organization/167319.pdf

${ }^{18}$ Amount converted using a rate of EUR $1=$ USD 1.34 on 7 August 2014.

${ }^{19} \mathrm{EU}$, 'Migration and Asylum Thematic Programme', retrieved 30 March 2014

http: / /ec.europa.eu/europeaid/how/finance/dci/migration_en.htm

${ }^{20}$ The Anti-Trafficking Monitoring Group, Wrong Kind of Victim? One Year On: An analysis of UK measures to protect trafficked persons, 2010 , pp. 7,13 . The report concluded that in practice, the UK had not established a system led by the principle that a person who has been trafficked has experienced abuse and requires time to recover before being exposed to the rigours of an immigration system that is designed to identify and remove people without entitlement to remain in the UK. The existing system is satisfying neither the provisions of the Convention nor the key principles of the rule of law itself. Pockets of local good practice contrast with the centralised system that lacks any formal coordination and seems to be failing to refer trafficked persons to assistance and protection. The system has so far failed to contribute significantly to either an increase in prosecutions or wider knowledge on trafficking. Further, the structures in place for children seem to have made it more difficult to protect child victims of trafficking.

${ }^{21}$ W Easterly, op. cit. p. 149. See also D Mosse, 'Is Good Policy Unimplementable? Reflections on the Ethnography of Aid Policy and Practice', Development and Change, vol. 35, issue 4, 2004, pp. 639-671.

${ }_{22}$ Whilst it is acknowledged that consultation with trafficked persons can be difficult, it is also slowly gaining traction as a critical element of the rights-based approach to accountability. See, for instance: $\mathrm{R}$ Surtees, After Trafficking: Experiences and Challenges in the (Re)integration of Trafficked Persons in the Greater Mekong Sub-region, United Nations Inter-agency Project on Human Trafficking/NEXUS Institute, Bangkok, 2013, retrieved 7 August 2014, http://www.nexusinstitute.net/publications/pdfs/After\%20trafficking_Experiences\%20and\%20challenges\%20in\%20(Re)integration \%20in\%20the\%20GMS.pdf
} 
A Nigerian official of the United Nations Office on Drugs and Crime (UNODC) observed, rather pragmatically, in response to the research question on how decisions on distribution of funds to the organisation's different operational areas are made: 'Distribution of our funding mostly depends on donor's priority areas or donor's interest, so to say. ${ }^{, 23}$ A United Nations Children's Fund (UNICEF) project, on the other hand, chose the more sustainable approach of community diagnostics and beneficiary consultation in designing and implementing the Nigeria Protection and Participation Programme-Child Protection Services Project (2003-2006). With a total budget of approximately USD 1.3 million, funded by the Swedish International Development Agency (SIDA), the project aimed at preventing trafficking by empowering youth at risk and giving them opportunities to learn and work in their home states. ${ }^{24}$ The project evaluation report observes that: 'The project does not focus on the more high-profile rescue and rehabilitation type operations often practiced under the child trafficking heading. Instead, it seeks to prevent harm from happening in the first place... Unfortunately, donors have been reluctant to support this type of preventive programme due to their lower profile: no traumatised victims can be put on display, there is no drama. It is therefore encouraging that UNICEF Nigeria has resisted the temptation to please potential donors, and argued for an approach that is likely to be more sustainable than most rescue-and-rehabilitation programs have turned out to be. ${ }^{25}$ In designing the project, UNICEF conducted participatory studies between 1998 and 2003 and a community appraisal led by twenty-four youth from the potential beneficiary pool in 2003. The main implementing partner of the project was Idia Renaissance, which has long-standing experience in working with youth in Edo state (routinely cited as the main area in Nigeria from where young women are trafficked).

Not only are funding decisions top-down, but they also often align with donor country priorities. ${ }^{26}$ Migration debates are highly political, and the nature of anti-trafficking funding has often tacitly (and sometimes quite overtly) advanced a foreign policy of stemming migrant flows towards donor countries. US State Department funding of anti-trafficking efforts, for instance, has been heavily criticised for ties to US foreign affairs agendas, ${ }^{27}$ but also more generally, anti-trafficking funding has been linked to receiving countries' immigration priorities. Though not funding Nigeria specifically at the moment, donor resources from the US for anti-trafficking in Africa broadly focus on what are supposedly 'voluntary' returns, investigations and prosecutions, and prevention through awareness. ${ }^{28}$ Tracing the history of EU cooperation with third countries in relation to migration management, Stephen Sterkx, in just one example, identifies the use of High-Level Working Group Action Plans in the late 1990s to establish dialogues with the most important countries of origin of migrants and asylum seekers. ${ }^{29}$ Following these Action Plans, in 2002, the governments of Spain and the UK proposed making development aid dependent on third

\footnotetext{
${ }^{23}$ Email response, UNODC official, Nigeria, 7 February 2014.

${ }^{24}$ UNICEF, Evaluation of UNICEF's SIDA-funded child protection/trafficking programme in West Africa, 2007, p.5.

25 Ibid., p.12.

${ }^{26} \mathrm{P}$ Hjertholm and $\mathrm{H}$ White, 'Survey of Foreign Aid: History, trends and allocation', discussion paper, Department of Economics, University of Copenhagen, 2000, p.3.

${ }^{27}$ See: Chuang, Janie A, 'The United States as Global Sheriff: Using unilateral sanctions to combat human trafficking', Michigan Journal of International Law, vol. 27, no. 2, 2006, http://ssrn.com/abstract=990098; AM DeStefano, The War on Human Trafficking: US policy assessed, Rutgers University Press, 2007, pp. 40-42.

${ }^{28}$ Though the largest anti-trafficking funder globally, the US Office to Monitor and Combat Trafficking in Persons has not funded Nigeria in its current 2013 programme cycle, though it did commit USD 4.7million for seven projects in Africa in 2013, covering 24-36 month cycles. This is a significant reduction, of over 70\%, from its total funding to Africa in 2010 . The majority of the funds were deployed for prevention-related awareness raising, capacity building trainings for law enforcement, legislative reforms and referral mechanisms. Only one of the seven projects is dedicated in part to victim support and re-integration. Office to Monitor and Combat Trafficking in Persons, Projects Funded during Fiscal Year 2013, 2 October 2013, retrieved 20 February 2014, http://www.state.gov/j/tip/rls/other/2013/215002.htm

${ }^{29}$ S Sterkx, 'The External Dimension of EU Migration Policy: Expanding fortress Europe?' in J Orbie (ed.), Europe's Global Role: External policies of the European Union, Ashgate, London, 2009, pp. 117-138.
} 
countries' efforts to combat illegal immigration and the mainstreaming of migration in all the EU's external relations. The proposition was accepted by all countries, except for the condition to impose sanctions for non-cooperating countries. ${ }^{30}$

With a look at how anti-trafficking programming in Nigeria has reflected this funding trend, from 2011 to 2012, the International Organization for Migration implemented the project Enhancing Multi-stakeholder Cooperation to Fight Human Trafficking in Countries of Origin and Destination within the framework of the UN.GIFT, with the participation of Austria, Belgium, France, Germany, Nigeria, Switzerland and the UK. The overall objective of the project was 'to stem irregular migration by preventing and combating trafficking in human beings between Nigeria and selected European countries. ${ }^{31}$ As noted by other examples in our study, the focus on prevention of migration and trafficking effectively excludes work that is urgently needed for victim re-integration. Some of the challenges noted by the Project were: 'Lack of specific grants to support empowerment activities (vocational training, reinsertion to school, business set up) for VoTs [victims of trafficking] where needed, challenges with NAPTIP and other NGOs in providing rehabilitation support for VoTs with international referral ...limited capacity of NAPTIP's legal unit in prosecuting trafficking cases, limited capacity of Shelters' staff to provide psycho-social and rehabilitation support to mentally handicapped VoTs, particularly with foreign VoTs, inadequate follow-up assistance to former VoTs who have been reintegrated. ${ }^{32}$

The EU is currently a major funder of Nigerian anti-trafficking measures, and a primary funder of UNODC's projects in the country. In August 2011, UNODC received an EU grant of USD 6,864,000 for a four-year programme aimed at 'promoting better management of migration in Nigeria by combating and reducing irregular migration that occurs, inter alia, through trafficking in persons (TIP) and smuggling of migrants (SOM)'. ${ }^{33}$ Anti-smuggling and antitrafficking efforts are intertwined for the same purpose of reducing outward migration.

In October 2012, the government of Nigeria, UNODC and the EU launched a three-year antitrafficking campaign throughout Nigeria entitled 'I am Priceless'. According to UNODC's website, the campaign is aimed at raising awareness about the reality, dangers and possible impact of irregular migration, as a consequence of either being smuggled or being a victim of trafficking in persons. Curiously, UNODC's threat assessment report, ${ }^{34}$ which largely informs the campaign, noted that poverty, desperation and weak governance fuel trafficking amongst young people in West Africa. While information campaigns can be useful, Nigeria is already saturated with them. ${ }^{35}$ When faced with the harsh economic realities of life in Nigeria today, an awareness campaign will not do much to discourage a young person from seeking a better life abroad. ${ }^{36}$

\footnotetext{
${ }^{30}$ Ibid., p.122.

${ }^{31}$ See: http://www.iomvienna.at/en/aktivitaeten/bekaempfung-des-menschenhandels/abgeschlossene-projekte/555-europenigeria-project-enhancing-multi-stakeholder-cooperation-to-fight-human-trafficking (retrieved 23 July, 2014).

32 IOM, A Brief on Activities Undertaken by IOM Nigeria at National Level on VoTs, provided by IOM official in Nigeria via email on 6 February 2014.

${ }^{33}$ Email response, UNODC official, Nigeria, 7 February 2014.

${ }^{34}$ UNODC, Transnational Trafficking and the Rule of Law in West Africa: A threat assessment, 2009, p.3.

${ }^{35}$ NAPTIP has a public enlightenment unit (one of its four main units) which manages nationwide television campaigns and adverts. Over the past thirteen years, there has been one television sit-com, several movies (of the popular Nigerian home video category) and numerous school outreach activities on the subject.

${ }^{36}$ Illustrative is the story of Faraenatu Amedu, captured in the BBC World Service radio documentary, Desperate Dreams in 2008 (retrieved 30 March 2014,

http://www.bbc.co.uk/worldservice/documentaries/2008/01/080115_desperate_dreams_part_two.shtml) who, upon returning to Nigeria-and back to the desperate financial circumstances that led her to migrate in the first place-without adequate care and support to guarantee her economic independence, was presumed to be re-trafficked two years later.
} 
The EU is also currently funding a number of NGO anti-trafficking projects in Nigeria. Of the six NGOs contacted, only WOTCLEF had information on this funding stream available on their website.

WOTCLEF is a national organisation with a presence in thirteen states of Nigeria. Its mission is to work 'towards the elimination of trafficking in persons, child labour, abuse of the rights of women, children and the spread of HIV/AIDS. ${ }^{37}$ The NGO has a small rehabilitation centre for child victims of trafficking in the Abuja and offices staffed by volunteers in four other states. The shelter in Abuja can accommodate thirty persons, and it only receives children below eighteen years of age. The objective of WOTCLEF's EU-funded project can be summarised as targeting school-going children, their parents, teachers and other caregivers and law enforcement officers with information and awareness to prevent human trafficking. ${ }^{38}$ The aim is to reach 8,230 people within the Federal Capital Territory with information. While this is a laudable initiative, it is not the most-needed resource for the organisation or for antitrafficking efforts in Nigeria. Abuja, like many other cities in the country, is affected by child trafficking, but it is not a critical source of child trafficking in or outside Nigeria. ${ }^{39}$

WOTCLEF's donations link on its website offers a glaring clue as to where their real needsand the needs of their clients-lie. WOTCLEF is the only NGO that provides re-integration services specifically to trafficked children through its shelter in Abuja. A fact-finding mission (by the Anti-Trafficking Legal Project (ATLeP) delegation) ${ }^{40}$ visited the shelter in 2011 and observed extreme challenges in terms of space, staff capacities and facilities. Available equipment was old and ill-maintained, and children were required to take turns preparing their meals as the organisation had limited helpers. WOTCLEF coordinator, Veronica Umaru, informed the delegation that while they used to sponsor children to university level, the NGO could no longer afford to do this as it is now being run largely on the personal funds of the founder. The plea on WOTCLEF's donations link $^{41}$ is for food items, clothes, toiletries, stationery items, children's books, scholarships for the children, a new freezer, volunteers to offer counselling support to children in the shelter, vehicle maintenance, painting to make the shelter more child-friendly, a power inverter, equipment for the skills training centre, first aid drugs and staff salaries. These demands would approximately cost an interested donor no more than 20 million NGN (about USD 122,000) a year. However, these objectives appear not to suit the interests of donors.

Nigerian government spending on anti-trafficking efforts through NAPTIP, ${ }^{42}$ though significant, has not been adequate to meet demands, especially for victim assistance services. According to the 2013 TIP Report: 'The Government of Nigeria allocated the equivalent of

\footnotetext{
${ }^{37}$ See: http: / /www.wotclefng.org, retrieved 26 February 2014, now suspended.

${ }^{38}$ Ibid.

${ }^{39}$ See: UNODC, Measures to Combat Human Trafficking in Nigeria, Benin and Togo, op.cit. pp. 11-28; UNICEF, Factsheet on Child Trafficking in Nigeria, 2007; NAPTIP Factsheet (undated), retrieved 8 August 2014,

http://www.naptip.gov.ng/docs/FACTSHEET0001.pdf. These documents indicate that the main source regions for child trafficking victims are states in the south, the far north and western Nigeria; and also largely from rural rather than urban cities.

${ }^{40}$ From 19-26 February 2011, the author of this article led a fact-finding mission to Nigeria with a delegation from the AntiTrafficking Legal Project (ATLeP), UK, and Women's Link Worldwide. The mission was funded by the Organization for Security and Co-operation in Europe/Office for Democratic Institutions and Human Rights. During the mission, the delegation visited shelters, and conducted interviews with NAPTIP, immigration, NGOs and UN organisations.

${ }^{41}$ See: http: / / www.wotclefng.org, retrieved 26 February 2014, now suspended.

${ }^{42}$ NAPTIP, in response to our enquiries, provided information on their activities from 2009 to 2012, their partnerships and their strategic plan for 2012 to 2017, but no information on funding. This left the author with only the TIP Report as the sole source of information on NAPTIP funding. Other channels of government spending on anti-trafficking efforts include specialised units within immigration and police, but information from these sources is not easily accessible.
} 
approximately US\$11.9 million to NAPTIP, a slight increase from the 2011 budget, and an additional equivalent of approximately US\$160,000 to help evacuate Nigerian victims of trafficking who were stranded in Côte d'Ivoire. State governments also contributed the equivalent of approximately US\$15,900 in additional funds to support NAPTIP efforts during the reporting period. ${ }^{43}$ Compared to the spending of other governments within the region, the spending of the Nigerian government in this area is significant. However, pitched against the scale of the problem and thereby the demand for NAPTIP services (for example, number of trafficked persons received by the agency requiring re-integration services, the state of the agency's facilities and the capacity-building needs of agency staff), government spending on anti-trafficking is insufficient to have the required impact. Successive US TIP Reports since 2009 have found the agency to be severely under-funded, especially in the areas of victim protection and prosecutions. The 2011 TIP Report noted: 'Despite a reported government appropriation of more than US\$7 million in funding to NAPTIP, the organization's inadequate operational capacity suggested a significant disparity between projected funds and actual disbursements to the agency. Throughout the year, investigators often were not provided funding for travel or access to a vehicle to investigate trafficking cases, and the agency relied almost entirely on foreign donor funding for training its staff. ${ }^{44}$ By 2013, the TIP Report noted: 'Overall, NAPTIP spent roughly one-fifth of its operational budget, or the equivalent of approximately US\$666,000, on victim protection and assistance during 2012. ${ }^{45}$ Helpfully, from this figure one could extrapolate that the total NAPTIP budget for the year might be five times greater than USD 666,000, amounting to USD 3,333,000.

The 2014 TIP Report ${ }^{46}$ observed that in 2013, the equivalent of approximately USD 20,000 was disbursed to only forty seven victims (out of 777 victims identified for assistance during the year) for purposes ranging from vocational training to school tuition, although not necessarily in equal amounts. The number of victims who benefitted is disproportionate to the total number of victims identified by NAPTIP within the same year, all of whom were eligible to receive funds for re-integration. Furthermore, the amount represents a significant reduction from the disbursement of the previous year in which USD 22,000 was made to only ten persons at an average of USD 2,200 per person. ${ }^{47}$ The disbursement in 2013 is approximately USD 425 per person representing an $80 \%$ reduction. More so, it is not clear what criteria were used to select only forty seven victims to receive support out of hundreds.

The Nigerian government does not fund NGO efforts to address trafficking in persons.

\section{Anti-Trafficking Efforts in Nigeria, Aid Dependency and the Accountability Quagmire}

Aid has its good and bad sides. The good side of foreign aid to the anti-trafficking sector in Nigeria is that it has fostered research, amplified information about the phenomenon to much of the population, spurred the development of legislation and structures to advance interventions, helped NGOs to start off and others to build on seeds already sown. ${ }^{48}$ However,

\footnotetext{
${ }^{43}$ US Department of State, TIP Report 2013, p. 286, retrieved 8 August 2014, http://www.state.gov/documents/organization/210741.pdf

${ }^{44}$ US Department of State, TIP Report 2011.

${ }^{45}$ TIP Report 2013, op. cit.

${ }^{46}$ See: US Department of State, TIP Report 2014, http://www.state.gov/documents/organization/226848.pdf, launched on 20 June 2014, retrieved on 23 July, 2014.

${ }^{47}$ TIP Report 2013, op. cit.

${ }^{48}$ UNODC, Measures to Combat Human Trafficking in Nigeria, Benin and Togo, 2006, op.cit. p. 83.
} 
anti-trafficking groups in Nigeria have a strong aid dependency. ${ }^{49}$ With this dependency comes the question: 'To whom are anti-trafficking interventions in Nigeria accountable?'

Easterly dwells in detail on charity-based aid, observing that lack of feedback (from intended beneficiaries) and poor accountability (to intended beneficiaries) is one of the most critical flaws in aid. ${ }^{50}$ The outcomes are often bad and may do more harm than good. Criticisms of foreign aid include: creating dependency cycles, stifling of local growth, limiting the ability of organisations to fundraise locally, creating a lack of local identity or weak resonance with the people NGOs claim to help, and even corruption-the rise of 'fake' groups established to capture some of the abundant foreign aid. An Open Democracy article states that: 'International solidarity is a wonderful idea, and the notion of transferring resources from North to South for good causes is morally attractive. The mechanics of doing this properly, however, are far more complex. ${ }^{, 51}$

The anti-trafficking 'industry' in Nigeria does not escape the morass of lack of aid accountability. Many of the Nigerian anti-trafficking NGOs, including the ones cited in this article, are limited to various degrees by insufficient funding. ${ }^{52}$ NAPTIP, a government body, also remains under-resourced from year to year in the area of victim assistance and protection. ${ }^{53}$ Accountability is essential in ensuring that donor funding and organisational spending meet the stated purpose. As Dupuy et al. have cautioned: 'Over time, many local NGOs became top-down groups nourished from abroad, rather than local products of a popular, grass-roots civic movement. ${ }^{54}$ Nowhere is this truer than in anti-trafficking work in Nigeria, where we have seen anti-trafficking organisations such as NAPTIP, WOTCLEF, Idia Renaissance and even UN agencies align their interventions with the objectives and priorities of donors, thereby advancing foreign donor policies.

What do trafficked persons really need, and do anti-trafficking interventions serve these needs? A Terre des Hommes report observed that after the repatriation of 261 Beninese children 'rescued' from a stone quarry in Nigeria in 2005, the traffic in children between Nigeria and Benin did not decline. ${ }^{55}$ The practice had flourished for over two decades and had become acceptable in the eyes of the different local populations, as it was rooted in their harsh economic realities. In one interview, a village inhabitant observed: 'When families don't have enough money to send a child to school, even if the child works well, they take the child out of school and send him to Nigeria, (meaning-to the stone pits).' While another village inhabitant asked: 'What are we going to receive from the people who won't allow us to send our children away?' Trafficked persons and vulnerable groups are asking the same questions of anti-trafficking organisations today. When Neil Howard interviewed community members in Benin in $2010,{ }^{56}$ he found that the dominant institutional narrative which drives

\footnotetext{
${ }^{49} \mathrm{Ibid}$.

${ }^{50}$ W Easterly, op. cit., pp. 14, 332; brackets added.

${ }^{51}$ K Dupuy, J Ron and A Prakash, 'Foreign Aid to Local NGOs: Good intentions, bad policy', Open Democracy, 2012, retrieved 26 February 2014, http://www.opendemocracy.net/kendra-dupuy-james-ron-aseem-prakash/foreign-aid-to-local-ngos-goodintentions-bad-policy

52 UNODC, Measures to Combat Human Trafficking in Nigeria, Benin and Togo, op.cit. p. 83.

${ }^{53}$ Successive US TIP Reports since 2009 have found the agency to be severely under-funded, especially in the area of victim protection and prosecutions. The question of under-funding is relative: anecdotal reports suggest that other Nigerian law enforcement agencies regard NAPTIP as much better funded than themselves. See page 10, paragraph 3 for a discussion of this.

${ }^{54} \mathrm{~K}$ Dupuy, J Ron and A Prakash, Foreign Aid to Local NGOs: Good intentions, bad policy, 2012.

${ }^{55}$ O Feneyrol, Little Hands of the Stone Quarries: Investigation of child trafficking between Benin and Nigeria, Terre des Hommes, 2005, p.21,32.

${ }^{56} \mathrm{~N}$ Howard, 'Accountable to Whom? Accountable for What? Understanding anti-child trafficking discourse and policy in southern Benin', Anti-Trafficking Review, issue 1, Global Alliance Against Traffic in Women, 2012, pp.43-59,

http://antitraffickingreview.org/index.php/atrjournal/article/view/21/23
} 
anti-trafficking interventions (that so-called victims of trafficking are unsuspecting and need to be protected by efforts to stem illegal migration) ignores the realities of so-called victims and their communities (i.e. a need to migrate and find work in the face of grinding poverty). In one of Howard's interviews with young labour migrants, their disdain for incongruous institutional interventions is apparent, 'Do NGOs, white people or the government come here and say that it's (migration for work) bad? Yes, loads. Why? Because they see that it can be hard, but they offer us no alternative. What do you say to them? When they come and speak to us, their words go in one ear and come out the other. We listen and then we ignore them. ${ }^{57}$

An example of community-led anti-trafficking prevention was supported by the Women's Consortium of Nigeria (WOCON) in Lagos state. WOCON, in partnership with the International Labour Organization's International Programme on the Elimination of Child Labour (ILO-IPEC) Project, began the programme 'Withdrawal and Re-integration of Children in Domestic Service and Prostitution' in 2002 in the town of Shaki, Oyo state. This rural border town was known for trafficking of children to Côte d'Ivoire, Guinea and Mali to work as hawkers and domestic servants. A comprehensive programme of open-air campaigning, market outreach and a consultative forum was conducted to raise awareness among the town's inhabitants. The community pointed out that one of the major reasons for child trafficking was the lack of income generating ventures available to them. WOCON proposed the commercialisation of honey, an abundant product in the town, to provide employment for the adult population. WOCON staff then made a representation to the state government on behalf of the Shaki community for the grant of cooperative credit facilities to assist the community in honey production. At the end of the programme, not only did the community vow to stop placing their children and wards in the hands of traffickers, they also established severe sanctions against those who violated the agreement. Since then, WOCON has used the success of this programme as a model to be replicated in other rural communities in Nigeria. ${ }^{58} \mathrm{An}$ impact evaluation of the initiative would be welcome to determine if the success of the programme has been sustained.

Eyben and Ferguson ${ }^{59}$ propose five categories of institutions or persons to which bilateral aid agencies, in particular, should be accountable: taxpayers in the donor country, government in the donor country, government in the recipient country, poor people in the recipient country, and the international human rights framework. The reality is different however. The International NGO Training and Research Centre (INTRAC) has found that: 'Whilst in theory accountability to local constituencies is important, in practice the funding processes hijack the accountability mechanisms and re-orient them towards Northern donors. ${ }^{60}$ Not only is programmatic direction determined by the donors, accountability is solely to them. No one is asking trafficked persons in Nigeria what they want before designing interventions; in the same vein, no one is accountable to them when projects-ostensibly for their good-fail to achieve much good in the end.

\footnotetext{
${ }^{57}$ Howard's interview questions in bold, op. cit. p. 49.

${ }^{58}$ WOCON, Nigeria, retrieved 26 February 2014, http://www.womenconsortiumofnigeria.org/node/index.php?q=children

${ }^{59}$ R Eyben and C Ferguson, 'How Can Donors Become More Accountable to Poor People?' in L Groves and R Hinton, Inclusive Aid:

Changing power and relationships in international development, Earthscan, London, 2005.

${ }^{60}$ INTRAC UK, 'Briefing Paper No. 6', July 2004, retrieved 26 February 2014,

http://cercle.lu/download/partenariats/INTRAC1autonomy1or1dependence.pdf
} 


\section{Conclusions and Recommendations}

This article opines that while trafficking in human beings is acknowledged as a problem of significant national and global proportions by successive government institutions and NGOs in Nigeria, response to it is driven by donor aid in a model that mirrors Easterly's postulation of a principal-agent relationship. Initial observations suggest that anti-trafficking funding has neither been sufficient to meet the scale of the problem nor relevant to the specific needs of groups at risk of trafficking, or of returnee trafficked persons. More so, the focus of funding has not sufficiently addressed the issue of promoting positive migration, protecting the rights of potential migrants and migrant workers, and ensuring a positive development outcome of migration for all.

Many critics of foreign aid in Africa vehemently demand that it be completely cut. Moyo, for instance, generally proposes trade instead of aid. ${ }^{61}$ Whilst this may help in some areas, such as overall economic growth with the potential to reduce poverty, in other areas such as emergencies and humanitarian crises (where government resources are inadequate to meet demand) or specific human rights promotion and protection (where advocates need to maintain credibility and independence), it would be a very unwise decision. Recommendations here are not to cut funds to anti-trafficking interventions in Nigeria but to make them more effective and, where possible, seek alternatives-especially with the attendant value of preserving organisational relevance and autonomy.

- Anti-trafficking interventions in Nigeria are not looking at the 'bigger picture'; the proliferation of awareness raising campaigns will do nothing to stop a young person from migrating, or a family from giving away their child when they are in desperate economic situations. Umaru of WOTCLEF was right when she cited widespread poverty as part of the cause of human trafficking, ${ }^{62}$ but her organisation does nothing to address this root cause; neither does it align itself with the broader human rights, development and anti-corruption efforts in Nigeria. There is a need to link antitrafficking efforts to the broader questions of poverty reduction and good governance in Nigeria.

- One of the many problems of aid identified by Easterly includes the planners' mentality of questioning: 'What the end of poverty requires of foreign aid.' He rephrases the question as: 'What can foreign aid do for poor people?' In the same vein, what can donor funds do for potential migrants and other vulnerable groups? Or, what can donor funds do to ensure successful return and re-integration of trafficked people? The question posed by a village inhabitant in the Terre des Hommes research in 2005 is the same question being asked of anti-trafficking organisations today: 'What are we going to receive from the people who won't allow us to send our children away?' Why is it proving too difficult for trafficking prevention initiatives to make this clear link and deploy funds to address it? Anti-trafficking donors could focus more on community-driven initiatives identified through the bottom-up approach proposing tangible and sustainable solutions to specific problems.

- Foreign donors should be facilitators rather than dictators of the anti-trafficking sector in Nigeria. Top-down decision making in funding support has not helped the situation.

\footnotetext{
${ }^{61}$ D Moyo, Dead Aid: Why aid is not working and how there is another way for Africa, Farrar, Straus and Giroux, New York, 2009.

${ }^{62}$ M Paul, 'WOTCLEF Blames Increase in Human Trafficking on Poverty', Daily Times online, retrieved 20 February 2014,

http://www.dailytimes.com.ng/article/wotclef-blames-increase-human-trafficking-poverty
} 
It appears from observation that the fulcrum of support to Nigeria to date has been prevention, not only of trafficking but also of migration. Foreign donors should instead observe keenly the stated needs of NGOs and their local constituencies, and channel support accordingly, especially needs borne out of locally grown ideas and innovations that are already working well. This approach would benefit from the recognition that some NGOs may either represent a constituency or fail to represent their constituencies effectively.

- To ensure their independence, anti-trafficking organisations in Nigeria could also fundraise locally to meet their specific needs. The potential pitfall with this approach is that certain issues may resonate negatively with local sensitivities or priorities and thereby may not attract local funding (for instance, where local philanthropists may value providing education to young people over protecting sex workers or lesbian, gay, bisexual and transgender rights).

- Foreign donors must promote accountability first to trafficked persons involved with the projects they fund, secondly to the human rights framework and then to themselves. This could be achieved through requiring concrete evidence of effective consultation with a project's intended beneficiaries throughout the project life cycle, and innovative as well as independent monitoring and evaluation mechanisms built into project design.

Victoria ljeoma Nwogu has been a Global Alliance Against Traffic in Women (GAATW) Board Member for Africa since 2008. She is a longstanding advocate for the rights-based approach to anti-trafficking interventions in Nigeria, and has contributed to shaping policy and legislation on the issue. Since 2011, Victoria has been a visiting Professor at the Legal Studies Department of the Central European University (CEU) in Budapest, Hungary, where she lectures a course on 'Human Rights in Africa with a Special Focus on Gender Issues'. Victoria has conducted research on diverse human rights issues and contributed to publications and conferences within the human rights community on gender and migration, human trafficking and women's rights in general. Most notably, she co-authored the anthology, Collateral Damage: The Impact of Anti-Trafficking Measures on Human Rights around the World (GAATW, 2007). Email: vickylegal@yahoo.co.uk

The content of this article does not reflect the views or policies of the UN, its Member States, or contributory organisations, nor does it imply any endorsement. The opinions and ideas expressed in this article are grounded in the research and technical work of the author in the anti-trafficking field. 